\title{
4 The Face of the World
}

\begin{abstract}
This chapter examines the trope of faciality in relation to extinction discourse. It starts by considering the way photography was recruited to the typological project of classifying the faces of humanity according to nineteenth-century biological theories of race. I show how the head-on facial portraiture, ranging from carte de visite collections through to anthropometric photography, lent visual concreteness to the idea that supposedly inferior races were to disappear from the face of the Earth. I then examine the longevity of this trope in two recent documentaries: Samsara (2011) and Human (2015). Although both films try to distance themselves from evolutionary human hierarchies, their programmatic adherence to the codes of nineteenth-century still portraiture, I suggest, reveals the persistence of colonial modes of looking.
\end{abstract}

Keywords: face, race, anthropology, extinction discourse, Samsara, Human

Whether or not the subject is already dead, every photograph is this catastrophe.

Roland Barthes

We have explored so far how film and related visual media have been recruited to a world-seeing project aimed at disclosing the nonhuman world: be it the Earth itself as a singular planet, the life forms unavailable to perception or else removed from view due to geographical distances, or the things and objects crowding the visible. But this is only half of the story. For photography and cinema, as the remainder of this book will examine, have been equally put to the service of visualising, ordering and cataloguing a human collective on the globe.

In such a project one particular image has exerted a special allure: the human face. Whereas painted facial portraits had been the privilege of an elite, moneyed few, the appearance and subsequent popularisation of

de Luca, T. Planetary Cinema. Film, Media and the Earth. Amsterdam: Amsterdam University Press, 2022 DOI: $10.5117 / 9789463729628$ _CHO4 
photography widened this social practice. By the late 1850 s, having one's own picture taken and sharing it with friends, relatives and acquaintances had become a widespread custom in many Western metropolises. The revolution that this signified cannot be overstated. As Hagi Kenaan observes, 'what serves as our most immediate carte de visite, our point of entry into the public visual sphere - the face - is something to which we ourselves do not have direct access. Our face escapes us'. ${ }^{1}$ Carte de visite, French for 'calling card', was, in fact, the very name given to these nineteenth-century photographic portraits of oneself. Previously confined to its reflection in mirrors or reflective surfaces, or at most to a painting hanging on the wall, the face became a thing one could hold in one's hands and give to others, newly reproducible and endlessly circulating.

But is the face ever a 'thing', like those we excavated in the last chapter? Not for the philosopher Jean-Paul Sartre, who writes: 'We discover, among things, certain beings we call faces. But they do not exist like things'. Things, for Sartre, have no mobility and hence no temporality: 'Things are piled up in the present, shivering but never budging from their place; the face, on the contrary, 'projects itself ahead of itself in space and time': it is 'visible transcendence. ${ }^{2}$ If we are to follow Sartre, this transcendental visibility may explain why faces immediately became privileged objects of attention for photography, which promised the fixing, via imaging, of this transcendence as subjects sat immobile for a long time in front of the camera.

But it does not fully explain why faces went global. For faces were held to exteriorise not only transcendence but also mental and intellectual traits which were themselves differentiated as they were mapped out across the planet and contrasted with the 'civilised', white European races. As Denise Ferreira da Silva argues in her influential Toward a Global Idea of Race (2007), nineteenth-century 'sciences of man', such as anthropology, instituted the racial as a global signifier through a 'grid of specification of human beings that identified each particular bodily form and the corresponding type of mind (mental functions) as coming from a particular global region or continent'. ${ }^{3}$ In this context, 'the skull constituted the primary object of research. The reason was simple.

$1 \quad H a g i$ Kenaan, 'The Selfie and the Face' in Julia Eckel, Jens Ruchatz and Sabine Wirth (eds.) Exploring the Selfie: Historical, Theoretical, and Analytical Approaches to Digital Self-Photography (Cham: Palgrave, 2018), 113-130; 119, emphasis in original.

2 Jean-Paul Sartre, 'Faces' in The Writings ofJean-Paul Sartre, eds. Michel Contat and Michel Rybalka (Evanston, IL: Northwestern University Press, 1974), 67-71; 71, emphasis in original.

3 Denise Ferreira da Silva, Toward a Global Idea of Race (Minneapolis and London: University of Minnesota Press, 2007), 126. 
Measurement of skulls would provide information about the volume and size of the brain'. ${ }^{4}$ The presumed mental inferiority of the 'others of Europe', which found visible form in the shape of their heads, acted as global indexes of specific geographical places that, it was believed, directly conditioned such inferiority. 'What distinguishes this moment', Ferreira da Silva maintains, 'is a deployment of historicity that presupposes globality as a stage of human differentiation'. 5 In other words, globality was not a mere background for scientific race-thinking but the very ontological context that produced and enabled the classification and ranking of humans in the first place.

Mirroring this global spatialisation of humanity along hierarchic lines was its temporalisation according to evolutionist paradigms. For humans were not only assigned different intellectual attributes depending on their geographical provenance; they were also placed along a unidirectional temporal arrow that denied futurity to some humans according to their position on the evolutionary ladder. As a 'specific branch of the dual ideologies of imperialism and racism', this 'extinction discourse', as Patrick Brantlinger has shown, postulated 'the inevitable disappearance of some or all primitive races' in the face of 'civilisation' and 'progress' ${ }^{6}$

Although not examined by Ferreira da Silva and Brantlinger, photography, and especially photographs of human faces (whether frontal or profile), were crucial disciplinary techniques deployed by the sciences of man to make visible planetary human differentiation and evolutionary extinction discourse. As I explore in this chapter, photography became not simply an appendage to anthropology but the very medium through which it validated its scientific authority as it measured and catalogued the heads of human beings while seeing as its mission the fixing for posterity of the 'always already vanishing others of Europe'. ${ }^{7}$ My driving questions in this chapter will be: How did the technological reproducibility of faces provide the means whereby a global arena could be mapped out and rendered visible, and a global humanity hierarchised according to evolutionary parameters? How, in other words, did faciality intersect with globality, and how was that intersection itself imbricated with an overdetermined mortality whose internal functioning principle was racial differentiation?

4 Ibid., 121.

5 Ibid., 117.

6 Patrick Brantlinger, Dark Vanishings: Discourse on the Extinction of Primitive Races, 1800-1930 (Ithaca, NY, and London: Cornell University Press, 2003), 1.

7 Ferreira da Silva, Toward a Global Idea of Race, 29. 
To answer these questions, I first consider the mysterious allure of the human face at photography's dawn, its status as a special image for the lens of the camera, in relation to the daguerreotype and the carte de visite. I then proceed to investigate the deployment of facial and anthropometric photography in global compilations of 'race-types' that implicitly or explicitly proposed the disappearance of 'primitive races' from the face of the Earth according to social-evolutionist paradigms. My focus will be varied but concentrate especially on the British case, given its importance for the foundation of anthropology as a discipline. Case studies will include anthropological treatises and compendia from the 1850 os onwards, but special attention will be given to 'popularisers' such as the Dammann brothers' 'atlas of types' Races of Mankind: Ethnological Photographic Gallery of the Various Races of Man (1876) and the illustrated serial The Living Races of Mankind (1901). This large temporal frame is necessary both because it enables us to see how photography became gradually valued in anthropological circles (in lieu of drawings of human faces) and because it allows us to evaluate how anthropology itself intermingled with popular visual culture, profiting from the carte de visite to then influence photographic serials and magazines at the turn of the century.

The final section of the chapter, in tune with this book's methodological approach, turns to contemporary documentaries that center on the human face as the common denominator of a differentiated humanity: Ron Fricke's Samsara (2011) and Yann Arthus-Bertrand's Human (2015). My rationale for choosing these documentaries is twofold. First, they programmatically adhere to the conventions of the portrait genre to the point that they subtract and/or downplay cinematic properties. Second, their galleries of humanity, not unlike their nineteenth-century counterparts, are equally concerned with human extinction, although in their case a disappearing humanity is no longer attributed to racial inferiority but to the prospect of global environmental catastrophe and population explosion. Nevertheless, as I hope to show, their allegiance to codes and features of the facial portrait reveals the persistence of a colonial gaze that is predicated on racial differentiation as a global signifier and qualifier.

\section{The Inter-Face}

The official genealogies of photography are well known. In 1837 France, Louis Daguerre recorded his first daguerreotype, a unique, 'positive' image formed on a metal plate coated with iodine vapours, which he showed publicly in 
1839. In that same year, in England, William Henry Fox Talbot recorded a 'negative' image on paper, or a collotype, from which other images could be printed. The daguerreotype, however, remained the medium of choice for many in view of its superior qualities, and its preferred visual object was the human face. For Walter Benjamin, this was symptomatic. In his 'The Work of Art in the Age of Mechanical Reproduction' (1935), he noted:

In photography, exhibition value begins to displace cult value all along the line. But cult value does not give way without resistance. It retires into an ultimate retrenchment: the human countenance. It is no accident that the portrait was the focal point of early photography. The cult of remembrance of loved ones, absent or dead, offers a last refuge for the cult value of the picture. For the last time the aura emanates from the early photographs in the fleeting expression of a human face. This is what constitutes their melancholy, incomparable beauty. ${ }^{8}$

Two things are worth noting here. For Benjamin, the uniqueness of the daguerreotype as a one-of-a-kind, glass-encased object finds itself replicated in the human face it represents, thereby preserving, for the last time, the aura of the image, its 'cult value'. ${ }^{9}$ Unlike the reproducible images it would soon give rise to, photography is here still an artisanal and unrepeatable process. It requires subjects to sit immobile for a long time, and thus retains, as Noa Steimatsky suggests, 'a sense of intensified temporality' by capturing 'something of the subject's unfolding into the image', not unlike 'the traditional portrait's phenomenological constitution. ${ }^{10}$

But equally important for Benjamin in this auratic process is the association of face with death, as it serves the purpose of remembering loved ones, absent or dead'. This ritualistic use of the face was not exactly new. In many ways, photography simply usurped the place that had once been occupied by the mummy portrait and the death mask: this, as is well known, was one of the main arguments put forward by André Bazin in his 'The Ontology of the

8 Walter Benjamin, Illuminations, ed. Hannah Arendt, trans. Harry Zohn (New York: Shocken Books, 2007), 225-226.

9 It must be noted that this is a revised position for Benjamin, who had written in 1931, in his essay on photography, that the daguerreotype could not entail an auratic process insofar 'as the camera records our likeness without returning our gaze'. He went on: 'To perceive the aura of an object we look at means to invest it with the ability to look at us in return'. Benjamin, Illuminations, 188.

10 Noa Steimatsky, The Face on Film (New York: Oxford University Press, 2017), 8. 
Photographic Image', originally published in $1945 \cdot{ }^{11}$ Taking up Bazin, Laura Mulvey drives the point home by noting that the connection between death and photography was 'understood very quickly in the nineteenth century as people adopted photography into the rituals of mourning and memorials. The deathbed photograph came to replace the death mask.' ${ }^{12}$ Already at its dawn, the photographic portrait thus latches on to the face both because of its promise of access into the subject's temporalised essence, a way of unlocking one's transcendence, and because of its immediate evocation of a time that is no more. To quote Roland Barthes: 'Whether or not the subject is already dead, every photograph is this catastrophe.'. ${ }^{13}$

By the late 1850 , thanks to the glass negative wet-collodion process and new cameras, the technological reproducibility that, for Benjamin, washed away the aura of facial photography was already a reality in full swing. But even though sitting times had been significantly reduced and multiple photographs could be printed at once on to light-sensitive papers, the idea that a photographed human face could reveal the subject's uniqueness, his or her aura if you will, remained in place thanks to the appearance and popularity of the carte de visite, or calling card.

Patented by Frenchman André-Adolphe-Eugène Disdéri in 1854, the carte de visite was an inexpensive, cardboard-mounted photograph of oneself, typically measuring $6 \times 10 \mathrm{~cm}$, that people exchanged with friends, acquaintances and relatives. As John Tagg has argued, insofar as portraiture had historically been an aristocratic practice and privilege, 'the rise of the photographic portrait' mirrors 'the rise of the middle and lower-middle classes towards greater social, economic and political importance.'. ${ }^{14}$ Facial portraits were, in this context, meant to assert individuality: a good portrait, in the tradition of the daguerreotype, was one that managed to reveal the subject's personality and essence through the face. But the advent of the carte de visite also meant, paradoxically, that individuality was submerged in uniformity, since studios often 'relied on a limited inventory of props, poses and backdrops' in order to secure the card's formal equivalence as an

11 André Bazin, What is Cinema?, volume 1, trans. Hugh Gray (Berkeley: University of California Press, 2005), 12.

12 Laura Mulvey, Death $24 x$ a Second: Stillness and the Moving Image (London: Reaktion Books, 2006), 59 .

13 Roland Barthes, Camera Lucida: Reflections on Photography, trans. Richard Howard (New York: Farrar, Straus and Giroux, 1981), 96.

14 John Tagg, The Burden of Representation: Essays on Photographies and Histories (Basingstoke, UK, and New York: Palgrave, 1988), 37. 
industrially reproducible image. ${ }^{15}$ And while, at first, technical limitations required the placement of subjects at a certain distance from the camera, often in rigid full-frontal postures because of still fairly long exposure times, soon the face became fuller and more centralised, sometimes highlighted with a vignetting effect. ${ }^{16}$

The carte de visite, in short, broadened the uses and reach of portraiture: not only was it now much cheaper to have one's picture taken, images of one's face and the face of others became circulating, interchangeable objects in a public sphere which, as recent scholarship has shown, can be deemed the precursor of contemporary social networks and the digital selfie. ${ }^{17}$ As Kenaan tells us, it is unsurprising that the face lends itself so easily to mechanical reproduction and multiplication. As a 'modality of self-expression and self-presentation' in itself, the face is already an image, an 'inter-face' that is 'never just present but always already in the mode of self-presenting. It is an entity whose essence lies in its turning toward the eye, in facing a viewer'. Hence, 'in the age of "technological reproducibility", the image seems to be a natural vehicle through which the primary self-presentation of the face can expand its reverberation in the public sphere. ${ }^{18}$

Though Kenaan's focus is on the selfie phenomenon, his remarks are applicable to the nineteenth-century carte de visite, the emergence of which institutes and formalises the face as a technologically reproducible mode of self-presentation. The impact of the carte de visite cannot be overestimated. For if the face is a special image because it is always already communicating and presenting even when seemingly it is not, the other, equally important, side of this process is that one's own face is always excluded from the field of visibility. We see other faces, which in turn see us, but we cannot see our own faces facing others. Sartre eloquently sums up: 'The trouble is that I don't see my face - or at least not at first. I carry it in front of me like a secret I am unaware of, and it is, on the contrary, the faces of others which teach me about my own'. ${ }^{19}$ In this context, the carte de visite - and the myriad portrait and self-portrait genres that would follow in its wake - both

15 Deborah Poole, Vision, Race, and Modernity: A Visual Economy of the Andean Image World (Princeton, NJ: Princeton University Press, 1997), 111.

16 William C. Darrah, Cartes de Visite in Nineteenth Century Photography (Gettysburg, Pennsylvania: W. C. Darrah Publisher, 1981), 26.

17 See, for example, Annie Rudd, 'Victorians Living in Public: Cartes de Visite as 19th-Century Social Media', Photography and Culture, 9:3 (2016): 195-217.

18 Kenaan, 'The Selfie and the Face', 120.

19 Sartre, 'Faces', 68. 
returns one's face to the field of visibility while formulating, via a doubling, the encounter with known others as a fundamentally inter-facial process.

The carte de visite, however, introduced faces beyond familiar faces. Seizing it as a tremendously lucrative business, studios published faces of celebrities, statesmen and members of royalty, while dispatching photographers to faraway corners of the world to record and gather the pictures of 'native' and 'primitive' races, often coded as such in terms of utensils, weapons, feathers, and body and face ornaments. A global network of images was then established, one in which cartes de visite, and later postcards and travel images, became items of transaction: they were purchased, collected and assembled in purposefully made albums that ordered a planetary humanity according to prevailing racist parameters. As Anne Maxwell observes:

By the 188 os almost every middle-class household in Britain, the USA, Australia and New Zealand could boast a photographic collection that included images of indigenous peoples. But Victorian collectors did not simply amass things; taking their cue from scientists, they arranged postcards and photographs into series and sets that resembled the hierarchical taxonomies of race. ${ }^{20}$

In these collections, pictures of native peoples pertained to a different modality. As Deborah Poole explains in her Vision, Race and Modernity (1997), unlike 'the bourgeois cartes, whose imagery retained a residual "use value" as likenesses of friends and relatives, the colonial or "native" cartes de visite portrayed anonymous and historyless subjects. ${ }^{21}$ In other words, while people may have assembled pictures of natives because they may have been curious to see what 'others' looked like, these photographs were collected not because of the individual subjects they portrayed but because they embodied a racial and physiognomic type - a visual typology that was made possible by the very formal uniformity of the carte de visite as a reproducible image.

In large part, the necessity to order, differentiate and classify humanity can be attributed to the sensation caused by Johann Caspar Lavater's Essays on Physiognomy (1775-1778) in the first half of the nineteenth century, according to which the character of a person was an immutable God-given

20 Anne Maxwell, Colonial Photography and Exhibitions: Representations of the 'Native' and the Making of European Identities (London and New York: Leicester University Press, 1999), 11. 21 Poole, Vision, Race, and Modernity, 140. 
attribution that could be read through his or her facial structures. ${ }^{22}$ While Lavater's 'science' had illustrious precursors, such as the physiognomic treatises by Giovanni Battista della Porta and Aristotle, its popularity was as unprecedented as it was historically specific. ${ }^{23}$ It constituted, as Stuart Ewen and Elizabeth Ewen have shown, a response to 'an expanding world, where interactions between European and non-European societies were intensifying', which in turn required 'a global map of physiognomic distinctions, a new hierarchy of inequality' in the face of an increasing proliferation of faces. ${ }^{24}$ The popularity of the carte de visite was, in this context, intimately aligned with prevailing racial and physiognomic discourses. No wonder it was soon adopted as a fundamental tool by the emerging discipline of anthropology, which, energised by photography, took upon itself the task of producing a global taxonomy of human difference.

In a sense, as Roslyn Poignant points out, 'carte-de-visite portraits [...] appeared to be the ready-made constituents of a scientific narrative waiting to be pieced together. The extension of control over bodies implicit in anthropometric photography was but a short step to take'. ${ }^{25}$ A measuring photographic system largely based on craniometry (and osteometry), anthropometry consolidated the Lavaterian idea that physical appearance revealed inner qualities of intellect and character along racial lines. ${ }^{26}$ In the UK, two anthropometric systems were devised in 1869, both of which were used as disciplinary and measuring tools in the service of British colonial governance. ${ }^{27}$ The first, created by John Lamprey, then secretary of England's Ethnological Society, displayed naked subjects in full-frontal and profile positions against a crisscrossed mesh made out of silk, the purpose of which was to delineate anatomical comparisons. ${ }^{28}$ For the second, created by the anthropologist Thomas Huxley, naked persons were placed against

\footnotetext{
22 As Poole notes, by the time Disdéri patented his invention, Lavater's book 'had gone through hundreds of editions' in France. Ibid., 110.

23 For a succinct and useful history of physiognomy, see Therese Davis, The Face on the Screen: Death, Recognition and Spectatorship (Bristol and Portland: Intellect, 2004), esp. 25-40.

24 Elizabeth Ewen and Stuart Ewen, Typecasting: On the Arts \& Sciences of Human Inequality (New York, Oakland, CA, and London: Seven Stories Press, 2008), 98.

25 Roslyn Poignant, 'Surveying the Field of View: The Making of the RAI Photographic Collection' in Elizabeth Edwards (ed.) Anthropology and Photography $1860-1920$ (New Haven and London: Yale University Press, in association with The Royal Anthropological Institute, London, 1994), 42-73; 57 .

26 Ewen and Ewen, Typecasting, 98.

27 See Maxwell, Colonial Photography, 41-42.

28 It is also worth noting that albumen prints of Lamprey's system were the first photographs to ever appear in the Journal of the Ethnological Society in 1869.
} 
a plain background and beside a measuring rod at a specific distance from the camera.

While shocking, these parametric standards were only the most extreme dehumanising version of what Elizabeth Edwards calls the 'scientific reference' of full-face and profile views, one that worked its way into personal portraiture as well as medical, military, forensic and penal uses of photography through the second half of the nineteenth century (and which of course persists in our time, not least in the guise of facial recognition technologies). ${ }^{29}$ Here, the allure of the face is no longer related to the subject's elusive identity; it becomes instead a tool that permits the mapping out and surveillance of disposable bodies deprived of subjectivity and accordingly reduced to pure physicality. As one of the originary pillars of such a project, anthropology thus institutes faciality, as connected with craniometry, as the descriptor of racial difference. But, as Ferreira da Silva reminds us, faciality was in itself not enough for this project, which needed a global stage. Or, as she puts it: 'the racial constitutes an effective political-symbolic strategy precisely because the subjects it institutes are situated differently, namely, in globality'. ${ }^{30}$ In this context, "the scientists of man attempted to prove, to establish with certainty (as a "necessary" and "objective" fact), what eighteenth-century naturalists could only describe and the philosophers who framed man could only postulate', namely the inferiority of the racialised. ${ }^{31}$

One of the main instruments used for this empiricist purpose, as discussed in the following section, was photography, hailed precisely on the basis of its 'objectivity' in a number of British anthropological treatises and publications - in opposition to unreliable, because subjective, drawings. ${ }^{32}$ But we will also see that anthropology did not merely want to draw a global map of human difference. As an epistemology that transformed individuals into specimens of race, anthropology's fascination with recording racial others across a differentiated global space was simultaneously informed by a social-evolutionist paradigm according to which the more mentally

29 Elizabeth Edwards, 'Evolving Images: Photography, Race, and Popular Darwinism' in D. Donald and J. Munro (eds.) Endless Forms: Darwin, Natural Sciences and the Visual Arts (New Haven, CT, and London: Yale University Press, 2009), 166-193; 189. On the aesthetics and uses of surveillance photography in the second half of the nineteenth century, see Tagg, The Burden of Representation, esp. 66-102. On facial recognition technologies, see Kelly A. Gates, Our Biometric Future: Facial Recognition Technology and the Culture of Surveillance (New York and London: New York University Press, 2011).

$3^{0}$ Ferreira da Silva, Toward a Global Idea of Race, 30.

31 Ibid., 120.

32 On the nineteenth-century discourse of mechanical objectivity, see Lorraine Daston and Peter Galison, Objectivity (New York: Zone Books, 2007), esp. 115-190. 
inferior you were, the less time on Earth you had. Hence it became urgent to record these races before they vanished off the face of the planet, an urgency which conferred a new sense of mortality on the photographed human face.

\section{Death's Head}

In 1839 the British ethnologist and humanitarian James Cowles Prichard published his essay 'The Extinction of Native Races'. Denouncing 'the modern system of colonization' as 'the harbinger of extermination of the native tribes', he argued for the necessity 'to record the history of the perishing tribes of the human family'.33 Prichard would take it upon himself to undertake such a task. In 1843, the same year he co-founded the Ethnological Society of London, he published The Natural History of Man; Comprising Inquiries into the Modifying Influence of Physical and Moral Agencies on the Different Tribes of the Human Family. This comprised dozens of sections on the physical and cultural differences between human races, and it reiterated the foundations of his ethnology as based on the principle of 'monogenesis', that is, the idea that all human races have a single and common origin, being thus 'of one species and one family'. ${ }^{4}$

Prichard's ethnological compendium would make history. In its wake came an explosion of similarly titled catalogues promising to compile the human races scattered across the globe. These included: Charles Pickering's The Races of Man and their Geographic Distribution (1850); Josiah Clark Nott and George Robins Gliddon's Types of Mankind (1854); Robert Knox's The Races of Man: A Philosophical Enquiry into the Influence of Race over the Destinies of Nations (1862); John G. Wood's The Natural History of Man; Being an Account of the Manners and Customs of the Uncivilised Races of Man (1868-1870); Robert Brown's multivolume The Races of Mankind:Being a Popular Description of the Characteristics, Manners and Customs of the Principal Varieties of the Human Family (1873-1876); C. and F.W. Dammann's Races of Mankind: Ethnological Photographic Gallery of the Various Races of Man (1876); and the serial magazine The Living Races of Mankind: A Popular Illustrated Account of the Customs, Habits, Pursuits, Feasts and Ceremonies

33 James Cowles Prichard, 'On the Extinction of Human Races', Edinburgh New Philosophical Journal 28 (1839): 166-170; 168, 169, 170.

34 James Cowles Prichard, The Natural History of Man; Comprising Inquiries into the Modifying Influence on Physical and Moral Agencies on the Different Tribes of the Human Family (London: Hippolyte Baillere, 1845), 546. 
of the Races of Mankind Throughout the World (1901), also published as a two-volume book. Let us look at some of these projects in order to explore how anthropology became increasingly dependent upon the photographed human face so as to postulate a globally distributed and differently fated humanity.

The trope of the 'human family', as the titles above suggest, was pervasive in nineteenth-century anthropology. Yet the differences between these projects were equally significant, revealing the shifting and sometimes conflicting frameworks shaping the discipline in its complex rapport with popular visual culture. For example, unlike Prichard's culturalist The Natural History of Man, Nott and Gliddon's Types of Mankind, published in the US, advanced the hotly debated 'polygenetic' thesis according to which different human races originated from different, not the same, stock. Meanwhile, Wood and Brown were busy in their self-appointed mission as anthropological popularisers in the UK, even if, as Douglas A. Lorimer has shown, their The Natural History of Man and The Races of Mankind 'made limited use of physical anthropology and relied mainly on travel literature': the result was generalising and distorting treatises 'on the moral and psychological characteristics of various peoples'.35 These two authors equally subscribed to the idea of a racial extinction whose outcome was as guilt-free as it was inevitable due to theology or 'progress'. Whereas, for Wood, 'the cause of extinction lies within the savage himself, and ought not to be attributed to the white man', for Brown, 'the decay of wild races', from Tasmanians to West Africans, was 'the effect of the collision of savage and civilised races [which] tends to the destruction of the former'. ${ }^{6}$

If the theory of polygenesis gave rise to a much more nefarious racism, insofar as it viewed human races as separate and fixed in their biological makeup, the many faces that the more enduring doctrine of monogenesis would assume was no less guilty of ranking humanity according to biological features that, it was believed, isomorphically evinced moral and intellectual traits. As Poignant explains:

35 Douglas A. Lorimer, Science, Race Relations and Resistance: Britain, 1870-1914 (Manchester and New York: Manchester University Press, 2013), 125.

36 John G. Wood, The Uncivilized Races of Men in All Countries of the World; Being a Comprehensive Account of Their Manners and Customs, and of Their Physical, Social, Mental, Moral and Religious Characteristics (San Francisco: J.A. Brainerd \& Company, 1883), 791; Robert Brown, The Races of Mankind: Being a Popular Description of the Characteristics, Manners and Customs of the Principal Varieties of The Human Family, volume III (London, Paris and New York: Cassell, Petter \& Galpin, 1887), 219. 
By the 1860 s an essentially historical Prichardian ethnology, which had attempted to establish a typology of the diverse races of mankind, was being gradually transformed by the Darwinian revolution in scientific thought into an anthropology that applied systematic methods of classification to produce developmental models of social evolution that were in essence hierarchical. ${ }^{37}$

This included the social-Darwinist paradigm according to which, as Brantlinger notes, 'nature's constant laws mandated the extinction of all unfit creatures and species to make room for new, supposedly fitter ones' ${ }^{3}{ }^{8}$ It followed that it was urgent to record the faces of such races before their vanishing, a task which photography was to fulfil in a number of ways and contexts.

In fact, the human face haunts ethnological and anthropological accounts even before mechanical photographic printing. As Alison Griffiths points out: 'it was tales of what intrepid travelers, colonial officials, and missionaries had seen on their trips to the far corners of the earth in the form of drawings, sketches, engravings [...] that thrilled the general public and scientific societies alike'. ${ }^{9}$ A case in point is Prichard's aforementioned The Natural History of Man. It included a number of steel and wood engravings of faces, many of them from the published accounts of the voyages of James Cook, Nicolas Baudin and Otto von Kotzebue, and which had, in turn, previously appeared in Johann Gottfried Schadow's 1835 publication National-Physiognomieen, thus confirming anthropology's foundational physiognomic proclivities. ${ }^{40}$ Though not as heavily illustrated, Pickering's The Races of Man also included 13 pictures, including one based on a daguerreotype and eight original drawings by engraver Alfred Thomas Agate. Nott and Gliddon's Types of Mankind similarly relied on second-hand drawings and engravings. When there is an original sketch in the book, as in 'the likenesses of two Negroes', although the authors suggest it can 'be considered caricatured', this is dispelled by their following, racist qualification that 'one need not travel far, to procure, in daguerreotype, features fully as animal'. ${ }^{41}$

37 Poignant, 'Surveying the Field of View', 45.

38 Brantlinger, Dark Vanishings, 15. As Brantlinger notes, Darwin himself stressed the superior qualities of the civilised man in relation to savages doomed to extinction due to nature's selective process (164-186).

39 Alison Griffiths, Wondrous Difference: Cinema, Anthropology, \& Turn-of-the-Century Visual Culture (New York: Columbia University Press, 2002), 88, emphasis in original.

40 Poignant, 'Surveying the Field of View', 57.

41 J.C. Nott and G.R. Gliddon, Types of Mankind, or Ethnological Researchers (Philadelphia: Lippincott, Grambo \& Co; London: Trübner \& Co, 1854), 260. 
The recourse and references to the daguerreotype in these surveys evince the increasing investment in photography as the enabler of typological projects based on facial evidence. It is no accident that one of the very first books to include photographs had the human face at its center. Thanks to the heliotype, a multiple-printing mechanical process, Darwin's The Expression of the Emotions in Man and Animals (1872) featured 30 photographs, 19 by the photographer Oscar Rejlander and eight copied, with permission, from plates that had appeared in Mécanisme de la physionomie humaine (1862) by the French clinician Guillaume-Benjamin Duchenne de Boulogne. ${ }^{42}$ Recognising the poor quality of some plates, Darwin justifies their inclusion by noting that 'they are faithful copies, and are much superior for my purpose to any drawing, however carefully executed'. ${ }^{43}$

By focusing on fleeting emotions rather than on 'the permanent form of the features', The Expression of the Emotions in Man and Animals attempted to distance itself from physiognomy. ${ }^{44}$ Yet it pertained to the same discursive nexus around the legibility of the human face, which subtended a variety of practices and disciplines in the second half of the nineteenth century, including anthropology. For Darwin, facial pictures served the purpose of highlighting universality, or as he put it, that 'the same state of mind is expressed throughout the world with remarkable uniformity [in] all the races of mankind', even if pictures of 'racial types' are conspicuously absent in his book. ${ }^{45}$ Conversely, in popular anthropological studies it was the opposite, that is to say physical difference, that was valued, as when Robert Brown, in the introduction to his 1882 The Peoples of the World (a republished version of The Races of Mankind) noted: 'Every individual is different in appearance. No two faces are exactly alike'. ${ }^{46}$

In any case, books such as The Expression of the Emotions in Man and Animals were still a rarity given the prohibitive costs of photographic printing. A more common practice, as noted earlier and stated in the preface to John G. Wood's The Natural History of Man, was 'for the countenances of

42 For an illuminating account of the use of photographs in Darwin's book, see Phillip Prodger, 'Photography and The Expression of the Emotions' in Charles Darwin, The Expression of the Emotions in Man and Animals, ed. Paul Ekman (New York: Oxford University Press, 1998), 399-410. 43 Charles Darwin, The Expression of the Emotions in Man and Animals (London:John Murray, 1892), viii.

44 Ibid., 1.

45 Ibid., 19.

46 Robert Brown, The Peoples of the World; Being a Popular Description of the Characteristics, Condition, and Customs of the Human Family (London, Paris and New York: Cassell, Petter, Galpin \& Co., 1882), 1 . 
the people [to] have been drawn from photographs'. ${ }^{47}$ But even when these drawings were based on photographs they still aroused suspicion. Thus, for the anthropologist and cultural evolutionist Edward B. Tylor, a central figure in the consolidation of anthropology as an academic discipline in the UK, the engravings in Wood's publication were still 'too picturesque and imaginative', and compared unfavourably with those featuring in Brown's The Races of Mankind, whose publication he accordingly welcomed in $1874.4^{8}$ Two years later, upon the publication of Carl Victor and Friedrich Wilhelm Dammann's photography book Races of Mankind:Ethnological Photographic Gallery of the Various Races of Man (1876; hereafter Ethnological Photographic Gallery), Tylor celebrated it as a watershed in racial studies. Its printed photographs, he maintained, evinced that 'most engravings of race-types to be found in books were worthless, either wanting the special characters of the race, or absurdly caricaturing them'. He concluded: 'Now-a-days, little ethnological value is attached to any but photographic portraits, and the skill of the collector lies in choosing the right individual as representatives of their nations'. ${ }^{49}$ In other words, these portrayed individuals were valued not because of their individuality, as in the bourgeois carte de visite. Rather, they typified a particular human race that was itself globally demarcated: they were, in short, a racial type. To put it in even cruder terms, the human face was no longer cherished because of the inner transcendence that it exteriorised but it was, on the contrary, reduced to pure exteriority: the sizes and shapes of the head that denoted 'expressions of levels of "development" of mental functions'.50

Ethnological Photographic Gallery was a concise edition of C. Dammann's monumental Anthropologisch-Ethnologisches Album Photographien (1873-1874). The original album comprised 642 photographs, many of which were anthropometric photographs and cartes de visite collected, re-photographed and assembled by Dammann for the Berlin Society for Anthropology, Ethnology and Prehistory. Dammann's 'atlas of types' evinced not only the widespread use of the calling card in taxonomical projects but also the social-evolutionist bent of such projects as they segregated and hierarchised humanity on a global arena (figures 4.1 and 4.2$) \cdot{ }^{5}$ As Teresa

47 John G. Wood, The Natural History of Man; Being an Account of the Manners and Customs of the Uncivilised Races of Man (London: George Routledge and Sons, 1868), v.

48 Edward B. Tylor, 'The Races of Mankind', Nature 9 (12 February 1874): 279-280; 279.

49 Edward B. Tylor, 'Dammann's Race Photographs', Nature 6 (6 January 1876): 184-185; 184.

50 Ferreira da Silva, Toward a Global Idea of Race, 124.

51 Another case in point is the attempt on the part of the British Association for the Advancement of Society (BAAS), in the late 1870 os and early 1880 s, to produce a survey of the origins of 

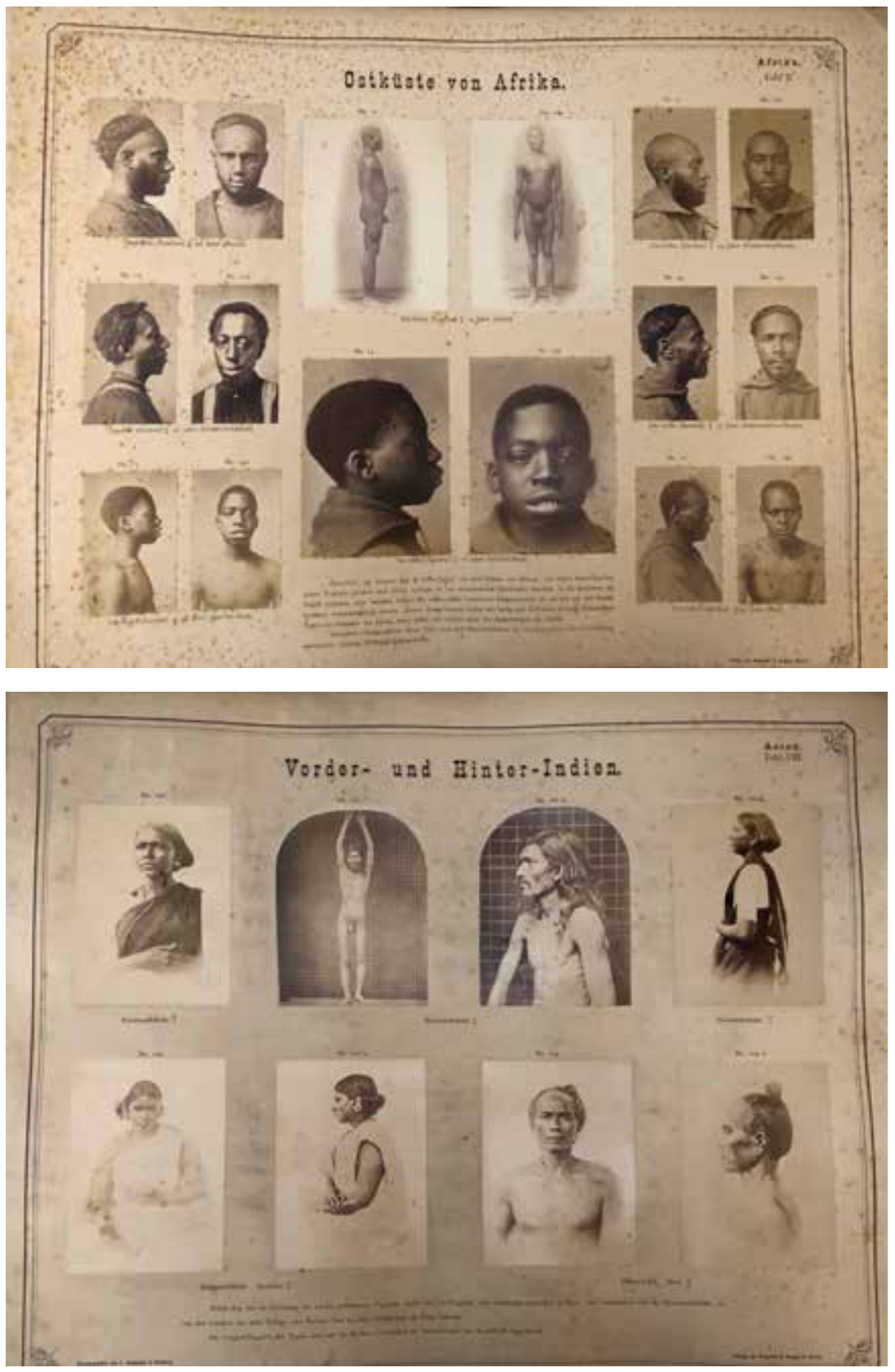

Figures 4.1 \& 4.2 Pages from C. \& F. Dammann's 'atlas of types' Races of Mankind: Ethnological Photographic Gallery of the Various Races of Man (1876) combine anthropometric photographs and cartes de visite, thus revealing their interchangeability in nineteenth-century galleries of humanity. Courtesy of the British Library. 
Castro notes, it is striking that the book version starts with 'German or Teutonic Types', the only section featuring individualised, that is, named persons - and all of whom were men, including Prince Bismark and David Livingstone - and ends with the 'Australians Aborigines' in a 'clearly racist and sexist logic of progression' ${ }^{52}$ Racist clichés regarding 'savages', from the 'state of utter barbarism' of Amazon tribes through to the 'rudest barbarism' of Australians, equally abound throughout the book.53

As much as it concerned itself with human difference, however, the impact of Ethnological Photographic Gallery was not as unequivocal as perhaps envisaged, even within anthropological circles. As Jane Lydon observes: "While mosaics of "types" had been compiled from the 1870 s onwards [...] to define difference within social-evolutionist frameworks, even some of the most committed Darwinists acknowledged the complexity and ambiguity of applying concepts of biological race to humankind'. ${ }^{54}$ For Lydon, evidence of this ambiguity is to be found in Tylor's aforementioned appraisal of Ethnological Photographic Gallery, which for him ultimately revealed likeness rather than difference: 'the real intricate blending of mankind from variety to variety'. ${ }^{55}$ Yet the ranking of Australians in the album was certainly in line with the belief that they stood at the bottom of the evolutionary ladder and risked imminent disappearance, thus evincing the album's ties with extinction discourse. ${ }^{5}$

the British population through cartes de visite and cabinet cards collected across the country. See Poignant, 'Surveying the Field of View', 57-61.

52 Teresa Castro, La pensée cartographique des images: Cinéma et culture visuelle (Lyon: Aléas Editeur, 2011), 170.

53 C. \& F.W Dammann, Ethnological Photographic Gallery of the Various Races of Man (London: Trübner \& Co. Ludgate Hill, 1876), plates XXI and XXIII.

54 Jane Lydon, Photography, Humanitarianism, Empire (London and New York: Bloomsbury, 2016), 111.

55 Tylor, quoted in Lydon, Photography, 111.

56 Thanks in no small part to Darwin's The Descent of Man (1871), this belief generated a flurry of photographic series that attempted to salvage the race for posterity. See Edwards, 'Evolving Images', 179. These series included the well-documented set of Australian photographs of five surviving Oyster Cove Australians, taken by Charles A. Wolley in his own studio and circulated as 'The Last of the Tasmanians' (see Poignant, 'Surveying the Field of View', 45); the work of the German-Australian photographer John William Lindt who, from 1868 to 1876 , took a number of pictures of aborigine peoples, in his studio in Grafton, New South Wales, carrying artisanal weapons and utensils as in a timeless tableau vivant; and the images taken by the French anthropologist Roland Bonaparte on the occasion of the French touring of the 'Australian Boomerang Throwers', described as the 'sole survivors of a party of nine Aborigines who were abducted by force in 1883 by the showman R.A. Cunningham' (see Maxwell, Colonial Photography and Exhibitions, 47). 
Ethnological Photographic Gallery is historically significant as the first photographic compilation of a global humanity. It paved the way for colonial serials and magazines published at the turn of the century, when advancements in photographic printing enabled their mass production and circulation. In Britain, one such serial was The Living Races of Mankind: A Popular Illustrated Account of the Customs, Habits, Pursuits, Feasts and Ceremonies of the Races of Mankind throughout the World, published in 1900. Imperialist to its core, its existence is attributed in the introduction (signed by Reverend Henry Neville Hutchinson) to the fact that the 'half-clothed savage, just emerging from the brute condition' can turn 'into a customer for British trade'. ${ }^{77}$ Equally important, its anthropological significance is exalted on the basis of its reliance on photography rather than drawings. Hutchinson goes on:

Pictures, or wood-engravings, may sometimes be prettier, but they can never be so absolutely trustworthy as the products of the camera [...] Many standard works on Ethnology are disfigured by engravings which are far from accurate, and in some cases are nothing less than parodies of the people they profess to portray. Even when a woodcut is prepared directly 'from a photograph', it cannot always be trusted..$^{8}$

Hutchinson's insistence that even photographic-based drawings are not comparable to actual photographs was probably a rebuke of Wood's and Brown's popularising efforts, examined earlier. He adds: the engraver 'has not studied anatomy, or the different types of human physiognomy, and to him there is very little difference between a Polynesian or a Papuan and an African negro'.59 In short, only photographs could illuminate those very little differences that formed the epistemological backbone of anthropology's global cataloguing.

Whether everyone perceived differences, however, is another story. For the British author H.G. Wells, such photographs produced the opposite effect. Noting the 'extraordinary intensifications of racial definition', or what he disparagingly called the 'race mania' of his time, he enthused that at last

57 Henry Neville Hutchinson, 'Introduction' in H.N. Hutchinson, J.W. Gregory and R. Lydekker, The Living Races of Mankind: A Popular Illustrated Account of the Customs, Habits, Pursuits, Feasts \& Ceremonies of the Races of Mankind throughout the World, volume I (London: Hutchinson \& Co, 1901), i-iv; ii.

58 Ibid., iv.

59 Ibid. 
there exists to-day available one kind at least of unbiased anthropological evidence. There are photographs. Let the reader turn over the pages of some such copiously illustrated work as The Living Races of Mankind, and look into the eyes of one alien face after another. Are they not very like the people one knows? ${ }^{60}$

Wells's statement is striking. It provides evidence that the celebrated objectivity of photography could be used to bolster both human difference and sameness. But Wells's position is also symptomatic, since his universalism emerges as a response to the 'race-mania' discourse of difference, to use his own words. As Mary Ann Doane remarks, thanks to its multiplication in urban centers and via technological reproducibility, " $t$ t] he face emerges as a particularly acute problem in modernity, raising the specter of an illegible strangeness and otherness. In such a context, the notion of the face as a universal language, leveling all differences, becomes especially attractive'. ${ }^{61}$ The aforementioned statements and ideas by Darwin and Tylor also subscribe to this logic.

Yet, as we have seen, an even more pernicious and pervasive way of suppressing the threat of otherness was by ranking it low in the ladder of humanity - so low, in fact, as to be literally vanishing. The Living Races of Mankind wholly perpetuated this discourse. Its introduction is illustrated with the then highly disseminated pictures of Krao, a child from the forest of Laos, and the Mexican Juliana Pastrana, both hirsute and advertised as a 'missing link' with ape ancestors and whose placement in the serial, as Maxwell notes, served 'as evidence for a hierarchical concept of evolution in which Europeans were set apart from "primitive" racial types'. ${ }^{62}$ Extinction is then underlined throughout as a natural and inevitable process. Opening the first chapter is the assertion that the Papuans 'have greatly declined in numbers since the white man brought them the vices and the diseases of civilisation'. ${ }^{3}$ Later, the indigenous population of the Sandwich Islands is said to have been reduced from 300,000 to 40,000 , while 'neither disease nor drunkenness offers a satisfactory explanation of the rapid dwindling'

6 H.G. Wells, A Modern Utopia (London: W. Collins Sons \& Co, 1905), 228-229, 233. See also Lydon, Photography, 110-113.

61 Mary Ann Doane, 'Facing a Universal Language', New German Critique 41:2 (2014): 111-124; 122.

62 Maxwell, Colonial Photography and Exhibitions, 55. For an account of how these pictures were used to bolster evolutionism, see Edwards, 'Evolving Images', 177-180.

63 Hutchinson et al., The Living Races of Mankind, 1. 

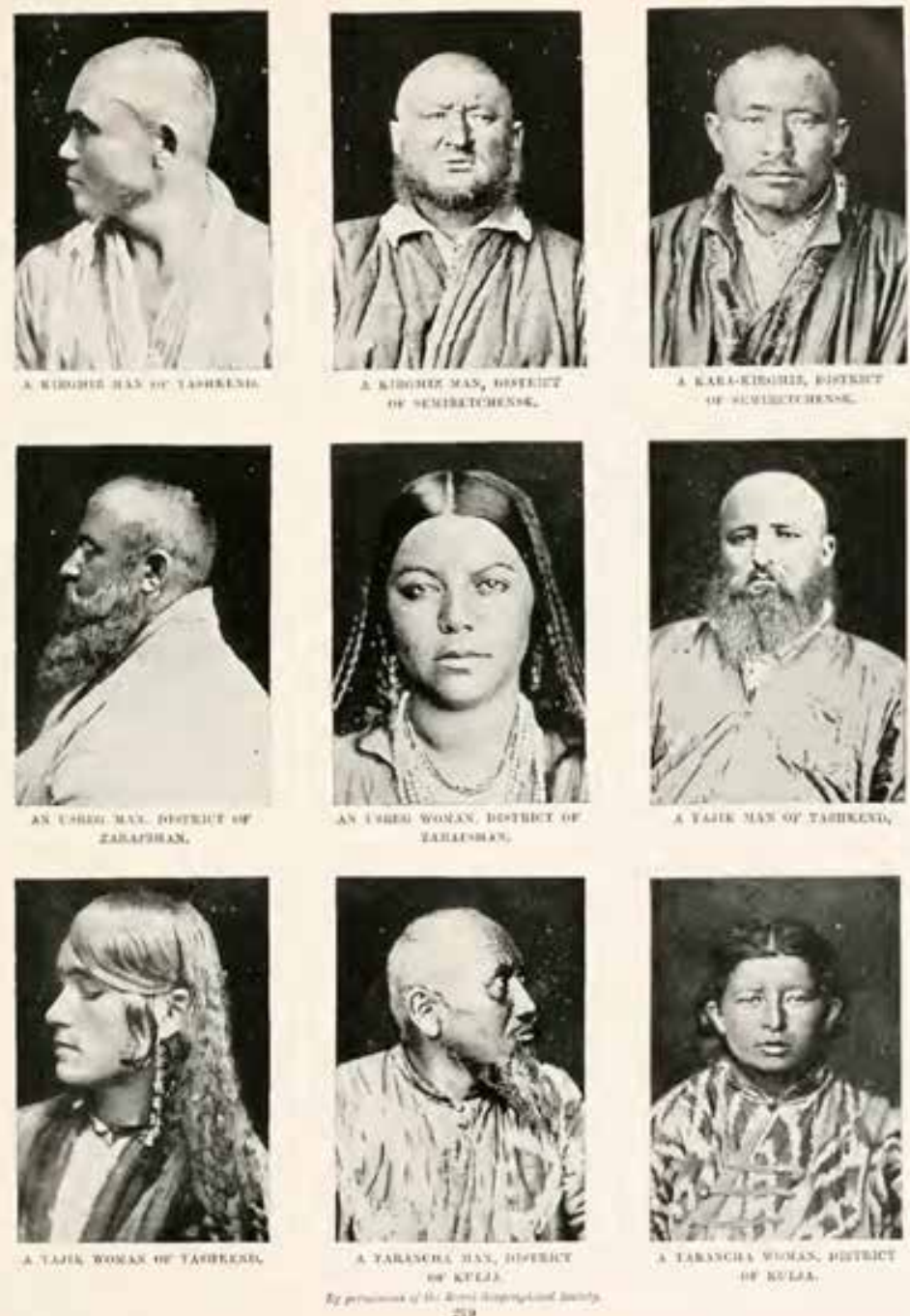

as

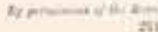

Figure 4.3 Frontal and profile facial pictures in The Living Races of Mankind (1901).

of the race. ${ }^{64}$ In another section, the Australian 'dark-coloured natives' are relegated to 'the bottom rungs of the ladder of human progress', and their rapid disappearance attributed to the 'shameful' 'advent of the white man in Australia': 'Civilisation, alas! brought disease and vice in its train'. ${ }^{65}$ Such 
an admission of guilt, however, is quickly countered with the statement that "[i]nferior races must of course give way and make room for those that are more highly civilised. ${ }^{6}{ }^{6}$

We can perhaps conclude from these statements that the living races' of the publication's title was to be taken quite literally, that is, as the intimation that some races are alive and well and the premonition that others do not share such a fate: hence the importance of photography in memorialising them. With 329 illustrations in total, the first volume of The Living Races of Mankind comprised 148 individual portraits, 137 group photos and 43 pictures of pairs, with images variously collected 'from professional and amateur photographs at home and abroad', including 'the ethnographical collections of Paris, Leyden, Hamburg, Dresden and Leipzig besides Oxford and Cambridge'. ${ }^{67}$ It features as a result an array of formats, sizes and styles, with pictures taken in situ, others in studios, and still others showing groups engaged in activities, dance and games. Yet, unsurprisingly, a significant portion of these images shows subjects in profile and frontal positions (figure 4.3) often isolated from their settings, whether through framing, a neutral background, or both.

Not all of these photographs were directly linked with extinction discourse, nor were all races portrayed as doomed. But it is fair to say that, by then, the frontal and profile facial portraits of nonwhites carried within themselves, that is, in their very formal structure and appearance, associations with death given the transactions and applications to which they had been subjected in the public sphere and anthropological domains. This was not the death denoted by pictures of deceased people adorning caskets or the more general sense of mortality attributed to photography per se, but a more specific, racialised death. Rather than standing by an individual who had passed away, such pictures instead suggested the disappearance of an entire human race. In place here, to cite Brantlinger, was 'the future-perfect mode of proleptic elegy [that] mourns the lost object before it is completely lost', that is, the 'work of cultural, national mourning occurs not because the aboriginals are already extinct but because they will sooner or later become extinct'. ${ }^{6}$

The longevity of facial portraiture cannot be overestimated when we consider the magazines that were to follow in the footsteps of The Living Races of Mankind, including, not least, National Geographic, founded in 1888 in the US by the National Geographic Society. As Catherine A. Lutz and Jane

67 Hutchinson, 'Introduction', iv.

68 Ibid., 4. That said, in some cases, such as the Tasmanians, total extinction did occur. 
L. Collins point out, the society was set up, like its British counterparts, in the midst of an anthropological 'search for evidence of the evolutionary backwardness of subaltern peoples'. ${ }^{69}$ The magazine supported such a project by 'position[ing] itself as a key actor in presenting "primitive" peoples for western perusal', with 'its encoding of hierarchy and power relations, and its projections of an inevitable outcome'. ${ }^{70}$

That outcome was disappearance. And while it was not until 1905 that photographs would become a common feature of the publication - and the magazine would nurture a range of photographic genres - the isolated frontal portrait of non-Western peoples would rank among its most favoured. As Lutz and Collins explain, National Geographic has reinforced ethnological codes by relying on a type of 'straight photography' that 'permitted the labors and point of view of the photographer and editor to recede into the background, thus encouraging the reader to see his or her contact with the photographed subject as unmediated, if necessarily indirect'. ${ }^{71}$ Here, in line with the precepts of popular anthropology and physiognomy, head-on frontality enables evaluation 'of the other as a person or type', a 'close examination of the photographed subject, including scrutiny of the face and eyes, which are in common-sense parlance the seat of soul'.$^{72}$ Editors are as a result in constant 'search for the "compelling face" in selecting photos for the magazine'. ${ }^{73}$

On the face of it a simple recording of native peoples looking into the camera, this 'straight photography', as I hope to have shown, has nothing straight about it. Caught at the intersection of discourses of faciality, raciality and globality, photography's objectivity was swiftly put to the service of a planetary human taxonomy according to which the future did not belong to everyone. Faces of difference, these photographs of human others acted as the conduit through which an overdetermined logic of racial differentiation gained a global - and deadly - face.

\section{'Don't Blink!'}

When it emerged, cinema immediately joined photography in the project of making visible faces in the world. As Griffiths observes: 'The iconography

69 Catherine A. Lutz and Jane L. Collins, Reading National Geographic (Chicago and London: University of Chicago Press, 1993), 19.

70 Lutz and Collins, Reading National Geographic, 19.

71 Ibid., 29.

72 Ibid., 199.

73 Ibid. 
of the "type" also found a home in early ethnographic film [...], functioning as a coded moment when film and photographic signification appear to collapse.'.74 In some travelogue films, as Jennifer Lynn Peterson has shown, 'the conventions of anthropometric photography, showing portraits of individuals frontally and in profile' are still evident, as in Moroccan Shoemakers (Pathé, 1915), 'where one witnesses a fascination with facial features that exceeds the film's attention to the local craft of shoemaking. ${ }^{75} \mathrm{~A}$ fascination with the face would similarly gain an illustrious place in early film theory, most notably in the writings of Béla Balázs and Jean Epstein, which, as Doane argues, tellingly revolved around 'the colonial encounter with otherness and its repercussions for identity'. ${ }^{6}$ She writes: 'It is striking that a critical focus on the face and the close-up invariably seems to return to a history of origins structured by the primitive-modern divide and one that inevitably $[\ldots]$ invokes questions of race. ${ }^{77}$

More recently, a focus on the racialised face has reemerged in earlycinema scholarship, which, according to Paula Amad, bespeaks an obsession with the 'return of the gaze' of film's colonial subjects. The aim, she notes, is to 'provide a textual compensation for the lack of photographic and cinematographic records made by peoples historically victimized by the camera', recovering facial looks and expressions as instances of resistance to the imperial gaze. ${ }^{7}$ Film's time-based properties are fundamental for this recovery. As Gunning argues, early cinema 'allowed the drama of the look to develop a more dialogic relation to its filmed subjects, whose faces and gestures gained a further expressiveness and independence as they were filmed in time..$^{79}$ Whereas, as discussed above, the facing gaze was the dominant convention of nineteenth-century racial portraits, in film the subject's look at the camera may not only emerge as an unintended element but also provide more sustained evidence of his or her feelings - discomfort, reluctance, animosity - at the time of registration. ${ }^{80}$ As Steimatsky sum-

74 Griffiths, Wondrous Difference, 114.

75 Jennifer Lynn Peterson, Education in the School of Dreams: Travelogues and Early Nonfiction Film (Durham, NC, and London: Duke University Press, 2013), 166.

76 Doane, 'Facing a Universal Language', 123.

77 Ibid., 119 .

78 Paula Amad, 'Visual Riposte: Looking Back at the Return of the Gaze as Postcolonial Theory's Gift to Film Studies', Cinema Journal 52:3 (2013): 49-74; 56 .

79 Tom Gunning, 'Before Documentary: Early Non-fiction Films and the "View" Aesthetic' in Jonathan Kahana (ed.) The Documentary Film Reader: History, Theory, Criticism (New York: Oxford University Press, 2016), 52-61; 61.

80 That said, in a parallel gesture, scholarship on colonial photographs sometimes also turns to faces as a means of reading facial expressions as evidential (if often speculative) indications 
marises: cinema, unlike photography, is often understood on the basis of 'its capacity to register, amplify, and perpetuate the face's expressive movements - the life of the face unfolding in time. ${ }^{81}$

Stillness and mobility, photography and film: the reproduction of the gazing face is indelibly implicated in questions of race and issues of medium specificity. We now turn to two contemporary documentaries, Samsara (2011) and Human (2015), which provide ample materials for an exploration of such questions and issues. I argue that these films emerge as irresistible case studies to compare and contrast with the global compilations of humanity examined earlier - despite (or rather, because of) the fact that more than a century separates them. First, this is because they implicitly or explicitly organise a human collective against the background of human extinction, though extinction is here differently conceptualised. Second, both films deliberately attempt to sacrifice and subtract the defining feature of film as a medium - that is to say, movement - in order to adhere more firmly to the medium of photography, and more specifically the conventions of the studio-based, background-free facial portrait. My contention is that this intermedial borrowing is not fortuitous but that it evinces, on the contrary, the continued longevity of anthropometric and ethnographic codes of racialised portraiture when ideas of a global humanity and human extinction are at stake.

Brantlinger argues that the wiping out of the entire humanity was an implied, if often dormant, feature of nineteenth-century extinction discourse. Citing Malthus's ideas of population growth, the eugenics movement and publications such as Wells's The War of the Worlds (1898), he writes that anxiety 'about the future of all the races of mankind - indeed, of the entire human species - was always implicit in extinction discourse'. ${ }^{82}$ Since the evolutionary paradigm postulated an ever-evolving human race, the idea that the white race 'would sooner or later vanish, experiencing the doom of the inferior races it had bested in the struggle for existence' was therefore always on the horizon. ${ }^{83}$ Yet there is little doubt that ideas of human extinction are today more widespread thanks to a global environmental crisis

of the relationship between photographer and photographed at the moment of capture. See, for example, Maxwell, Colonial Photography, 45-46; Robert W. Rydell, 'Souvenirs of Imperialism' in Christraud M. Geary and Virginia-Lee Webb (eds.) Delivering Views: Distant Cultures in Early Postcards (Washington and London: Smithsonian University Press, 1998), 47-63; 60.

81 Steimatsky, The Face on Film, 6. See also Paul Coates, Screening the Face (Basingstoke: Palgrave Macmillan, 2012) for another study on cinema's facial visuality.

82 Brantlinger, Dark Vanishings, 15 .

83 Ibid., 192. 
that increasingly generates doubts about the future. In some predictive scenarios, the question is not so much if but for how long the conditions necessary for human life may still be maintained, which relativises humanity in vaster - the Earth's own - trajectories and frameworks. ${ }^{84}$ As Déborah Danowski and Eduardo Viveiros de Castro summarise:

The idea that our species is a newcomer on the planet, that history as we know it (agriculture, cities, writing) is even more recent, and that the energy-intensive, fossil-fuel based industrial way of life began only a second ago in terms of Homo sapiens' evolutionary clock all seem to point to the conclusion that humankind itself is a catastrophe: a sudden, devastating event in the planet's biological and geophysical history, one that will disappear much faster than the changes it will have occasioned in the Earth's thermodynamic regime and biological balance. ${ }^{85}$

But this idea is also a double-edged sword. On the one hand, it can be deployed to underline the pressing need for collective action in the face of an impending global catastrophe. As I will argue in chapter 6, projects such as The Last Pictures (2012) and Homo Sapiens (2016) visualise nonhuman futures in order to make us confront the world in the here and now. On the other hand, this same idea can reiterate the pernicious logic of inevitability that has often informed extinction discourses, even if from within a different conceptual space. To different extents, as my analysis will show, both Samsara and Human perpetuate the latter logic. It is therefore symptomatic that they make recourse to the face in their elegiac visions of a human world. Let us look first at Samsara.

Directed by Ron Fricke, Samsara (2011) can be deemed a variation of the 'world symphony' genre discussed in the last chapter and whose incarnations also include Godfrey Reggio's Koyaanisqatsi (1982) - on which Fricke worked as cinematographer - and Fricke's own Baraka (1992). Samsara features Fricke's signature style developed in those earlier films: no voiceover or interviews, dazzling aerial images, and time-lapse shots of natural and human-made settings. Shot on $70 \mathrm{~mm}$ in 25 different countries over five years, Samsara's global travelogue is structured around a cyclical notion

84 Christiana Figueres and Tom Rivett-Carnac, "The Only Uncertainty Is How Long We'll Last": A Worst Case Scenario for the Climate in 2050', The Guardian (15 February 2020), https://www. theguardian.com/environment/2020/feb/15/worst-case-scenario-2050-climate-crisis-futurewe-choose-christiana-figueres-tom-rivett-carnac (last accessed 1 January 2021).

85 Déborah Danowski and Eduardo Viveiros de Castro, The Ends of the World, trans. Rodrigo Nunes (Cambridge and Malden, MA: Polity Press, 2017), 15. 
of life on Earth which is encapsulated in its title, a Sanskrit word meaning 'the turning wheel of life'. Here, as in Koyaanisqatsi and Baraka - the former meaning 'life out of balance' in the Hopi language and the latter a Sufi word for 'blessing' - the choice of a titular Hindu expression aims to position Samsara within the purview of Eastern spirituality and belief systems, as reinforced by its 'world music' soundtrack, composed by Lisa Gerrard, Marcello de Francisci and Michael Stearns. Nevertheless, as we shall see, Samsara's gaze on the world, with its marked reliance on orientalist conventions and racialised tropes, is a flagrantly Western one.

The idea of cyclicality is mirrored by Samsara's tripartite structure, with the film bookended by the image of a mandala, filmed at the Thikse monastery in India, being painted by monks at its opening and destroyed at its end. The first part, lasting roughly 30 minutes, combines images devoid of humanity, many filmed in ancient settings and natural environments, including: salt lakes in Bolivia, Naukluft National Park in Namibia, Antelope Canyon in Arizona and Mono Lake in California. The aim of these balletic images of sand deserts, dunes, lakes, glaciers and rock formations, often shot with a slow-moving camera in time-lapse cinematography, is plain and simple: the visualisation of a geophysical history where humans play no part.

But this quickly changes in the film's second part, where humanity rises as a planetary force to be reckoned with. Human faces and signs are first seen in a series of images of native villages in Ethiopia and Namibia, after which the film cuts to an aerial, night-time image of Los Angeles. What follows is a frenetic montage of sped-up images of crowded prisons, subways, factories and supermarkets. Filmed in bustling urban centers, such as Hong Kong, Tokyo, Shanghai and São Paulo, these images connote industrial modernity's intense and imbalanced relation with nature. In the film's last and briefest part (around 10 minutes), the prevailing themes are spirituality and religion, duly illustrated by images of Jewish synagogues, Catholic churches and Muslim temples. This includes an aerial shot of Mecca where the sea of people walking in circles down below transmogrifies into an undifferentiated mass through time-lapse. As the mandala is destroyed, the film then closes with human-free images of sand dunes.

The message is clear: humans, whether as agents or victims of a voracious and unrelenting modernity, are testing the limits of the Earth and its natural resources. The notion of impermanence, central to Buddhist and Hindu belief systems, is thus mapped on to the cycle of human existence, parenthetically situated within a much vaster planetary history. As Zoë Druick observes, here the viewer must either 'succumb to the inability to do anything but grit your teeth and experience the speed of life out of balance, or to realize that 
all this, too, will, in the cosmic scheme of things, pass. ${ }^{86}$ Indeed, there is not so much a sense of mourning for humanity's demise or a call to action in the face of socio-economic injustices and environmental ravages. Through the conceit of cyclicality, destruction is depicted as a perhaps undesirable but certainly inevitable process and, in doing so, Samsara recycles and updates nineteenth-century extinction narratives and tropes, including a programmatic adherence to the immobile human gaze.

Martin Roberts has argued that Baraka is illustrative of a 'coffee-table globalism', as its 'panoramic vision of global natural and cultural diversity [...] locate[s] it firmly within the humanistic documentary tradition of National Geographic' ${ }^{87}$ This also applies to Samsara, which claims its place within a photographic lineage even more overtly by framing motionless subjects without blinking when posing for the camera, a stilling of facial mobility that was duly publicised in promotional materials. On the official website dedicated to Baraka and Samsara, which includes an interactive world map where users can see the locations where the films were shot, the latter film is described thus: the 'filmmakers approach non verbal filmmaking with an understanding that it must live up to the standard of great still photography, revealing the essence of a subject, not just its physical presence'. ${ }^{88}$ Elsewhere Fricke has noted: 'All the direction on the portraits was just, "Look into the camera and don't blink!” Because blinking portraits don't work too well. It was the stare we were after to connect everyone together. No matter who you are, where you are, you see that soul. ${ }^{89}$

These statements cannot be overestimated. Not only do they seem lifted straight out of nineteenth-century physiognomic treatises and photographic guidebooks, they also evince how Samsara's take on the ethnographic portrait emulates the lengthy exposure times of early photography, as a result of which subjects had to remain immobile looking intently into the camera. In total, Samsara features 65 subjects posing for the camera

86 Zoë Druick, 'On (Not) Falling from the Sky: Fly-Over Global Documentary as Capitalist Body Genre' in Steve Anderson and Christie Milliken (eds.) Reclaiming Popular Documentary (Bloomington: Indiana University Press, 2021). My thanks to Druick for sharing a pre-print version of her chapter.

87 Martin Roberts, 'Baraka: World Cinema and the Global Culture Industry', Cinema Journal 37:3 (1998): 62-82; 67, 68 .

88 'About Samsara', https://www.barakasamsara.com/samsara/about (last accessed December 17 2018).

89 The Creators Project Staff, 'Capturing the Stunning Cinematography in Samsara: Q\&A with the Film's Director and Producer', Vice (6 September 2012), https://www.vice.com/ en_au/article/gadewe/capturing-the-stunning-cinematography-in-isamsarai-qa-with-thefilms-director-and-producer (last accessed 17 December 2018). 

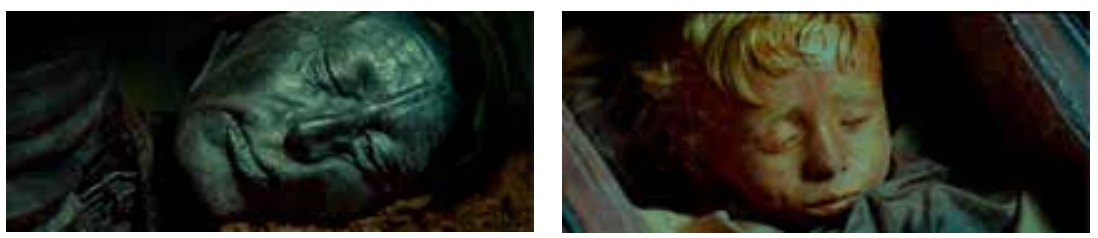

Figures $4.4 \& 4.5$ Images of mummified faces set up a connection between face and mortality in Samsara (2011). Courtesy of Magidson Films Inc.

during its running time..$^{\circ}$ These vary compositionally, with group shots, two shots and medium shots, yet facial close-ups dominate the film. A few subjects appear both in group shots and alone in short-distance shots, and the majority of these portraits, as per Fricke's instructions, display motion only in the form of a deliberate camera closing in on unblinking subjects. Whether or not these cinematic portraits reveal the soul of the face as intended by the director would be impossible to ascertain. But it is fair to argue that subtraction of movement here works in tandem with Barthes's famous contention that the unfolding presentness of filmic motion thwarts the connotations of pastness and mortality identified with photography. ${ }^{91}$ Put simply, facial immobility in Samsara is deployed to evoke death.

This is confirmed already in the film's opening, which uncannily materialises a Bazinian genealogy by showing in succession the face of an embalmed corpse, a mummified face (figure 4.4) and an Egyptian death mask (the pharaoh King Tut, c.1341-c.1323 BC). As the first part of the film unfolds, this genealogy is reinforced via shots of the Mount Nemrut statue faces in Turkey (which are believed to surround a royal tomb dating from the first century BC), and facial close-ups of Rosalia Lombardo (figure 4.5), an Italian child who died in 1920 and whose mummified body can be visited in the Capuchin catacombs of Palermo. These embalmed, sculpted and mummified faces therefore confirm the anticipated spectatorship envisaged by the film when it comes to its (moving) images of (still) living humans parading thereafter: they are to be read as indexical signifiers of mortality.

At the same time, Samsara adheres to an evolutionary narrative of faciality that recalls nineteenth-century taxonomies of races while intimating the disfigurement of humanity, its increasing unrecognisability. This is what happens, for example, when the film transitions to the second part, which

9o Three of these shots include adults carrying babies, and I am not counting the babies. I am also not counting a montage sequence showing nine children being baptised in a catholic church in Brazil, given that they are not posing for the camera.

91 Barthes, Camera Lucida, 78-80. 

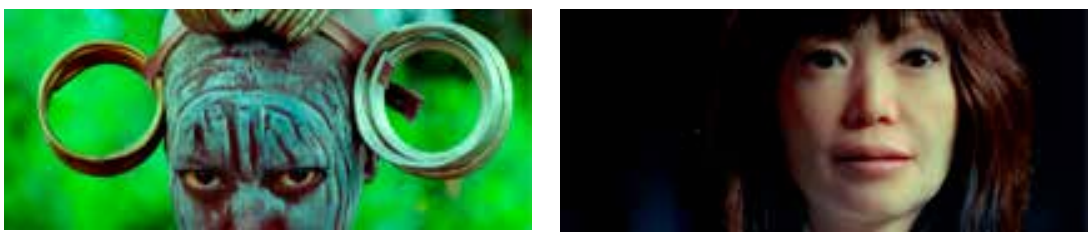

Figures 4.6 \& 4.7 Pictures from a Mursi Village local and a Japanese android convey an evolutionary narrative of faciality that hinges on well-worn tropes of the primitive and the modern. Courtesy of Magidson Films Inc.

cuts from portraits of Mursi Village locals (Ethiopia) (figure 4.6) and Himba tribe (Namibia) members to a two-shot of Hiroshi Ishiguro, an eminent Japanese specialist in robotics, beside his lookalike android. A close-up of the android facing the camera appears next, followed by a close-up of a Japanese female android whose uncanny resemblance to a human face (figure 4.7) is then dispelled by her machinelike sounds. In a later sequence, a high-angle shot of a woman about to undergo facial plastic surgery gives way to a montage alternating faces of sex dolls and faces of strip girls. The sequence ends with a Japanese woman, in a geisha costume, staring into the camera while a tear drops down her face.

These juxtapositions are hardly unambiguous. Human faces, Samsara laments, are becoming gradually and dangerously indistinguishable from human-made ones. In another, preceding, sequence, this process of defacement is even more literal. It depicts, to a discordant soundtrack, the French artist and sculptor Olivier de Sagazan spasmodically applying layers of clay and paint onto his face, which turns as a result into amorphous and monstrous shapes. Therese Davis has argued that the 'image of a face becoming unrecognisable makes death visible', and this is why this filmed performance, which makes visible this process of unrecognisability, occupies such a central place in Samsara.$^{92}$ For Davis, the profusion of dead faces in contemporary media (especially television) has anesthetised us to death. Conversely, for her, the representation of a face becoming unrecognisable is a more 'viable site for the transmission of death' as it expresses 'the transient nature of human existence', making us confront 'finality, irreversibility, absolute otherness', in short, the passage of time. ${ }^{93}$

These remarks are applicable to de Sagazan's filmed performance. But they also raise questions relating not so much to the 'absolute otherness' of time but the 'absolute otherness' of the film's racialised faces. Indeed, there 
is a noticeable lack of white countenances in Samsara (eight in total), and when these appear they are tellingly pierced, tattooed, and, in the case of US soldier Bobby Henline, disfigured by burning. In the film, then, the focus is on facial difference and a purported abnormality, one that tacitly assumes the white face - conspicuous by its absence - as the parameter against which 'others' can be measured. In this context, it is significant that it is a white face (de Sagazan's) that undergoes the process of transfiguration mentioned above. For this contradicts Samsara's predilection for non-Western peoples (including subjects from Indonesia, China, Ethiopia, Namibia, Japan, the Philippines and Accra): from the wide-eyed, heavily made-up Balinese dancers performing the Legong dance at the beginning through to the braided, red-tinged Himba natives, Samsara consistently relies on figures of the exotic. This also applies to the modernity end of the spectrum, which in the film is related, predictably, to Japanese faces, robotic or otherwise. Another way of putting this would be to say that whereas a white face can express in the film the 'transient nature of human existence' through a performance that theatricalises such transience, the otherwise non-Western faces parading throughout are deemed unworthy of transformation and thus denied the passage of time, that is to say, existence itself. Immobilised in their unblinking stare, these faces are not exactly becoming unrecognisable so much as they already are the face of death.

Samsara's racialised gaze thus reveals a logic that reinforces whiteness as an invisible (because hegemonic) and qualitatively different ethnicity, not unlike previous catalogues of human difference. Given that this is a film whose extinction discourse is meant to encompass the whole of humanity, it is therefore striking that its collection of gazing subjects - themselves inserted within a history that has accorded them connotations of mortality according to evolutionist paradigms - hardly include white faces, who are not only assumed to be unworthy of the scrutinising gaze of the camera (presumably because they are behind it) but also, one wonders, to be immune to the global cataclysm that the film anticipates in its theme and structure.

\section{The Face in the Crowd}

In some respects, Yann Arthus-Bertrand's Human (2015) offers a corrective to Samsara by including faces from most parts of the world. What is more, not only do these have a share of screen time, but they are also given the opportunity to speak to the camera during personal testimonies. By eschewing a fetishising stillness and muteness of subjects, Human might 
thus be commended for reinstating facial movement and giving a voice to the subjects it interviews. On closer inspection, however, the film also resonates with colonial portraiture by subscribing to an anthropometric aesthetics of enumeration and uniformity, one that gains in significance in light of the film's investment in questions of overpopulation.

That Human reveals ties with portraiture is perhaps not surprising in view of Arthus-Bertrand's professional experience as a photo-journalist for National Geographic, Geo and Life magazines. That said, Arthus-Bertrand's visual brand is now predominantly associated with the aerial view technique, which he has obsessively employed in a number of photographic and cinematic projects over the last two decades. Examples include the bestseller The Earth from the Air (1999) and the documentaries Home (2009), A Thirsty World (2012) and Terra (2015). Often referred to, ironically, as France's answer to Al Gore, Arthus-Bertrand is a controversial high-profile figure: the customary target of criticism on the basis of his landscape aestheticising and costly helicopter shooting, he is the founder of the non-profit organisation GoodPlanet Foundation (behind many of his projects) and also Environment Goodwill Ambassador for the United Nations.

Though still peppered with his trademark views from above, Human's most distinguished feature is its statistical reliance on the frontal face. Two years in the making, the film was shot in 60 countries and amassed over 2,000 interviews, largely with anonymous people (though exceptions include former Uruguay president José Mujica and actress Cameron Diaz). Human was part of a multimedia project comprising a number of audiovisual texts and artefacts, including: two theatrical films, making-of documentaries, educational projects, and promotional and photography books. The project's official release, on 12 September 2015, coincided with a public screening at the United Nations with Secretary General Ban Ki-moon in attendance, followed by a debate to mark the 7oth anniversary of the United Nations. On that same day the film was made freely available as three volumes of 90 minutes each on YouTube and Google Play in a number of languages, with longer interviews also available as individual clips on an exclusive YouTube channel. At the time of writing, the film's first instalment has over 6 million views.

Human evolved from Arthus-Bertrand's web-based database project 7 Billion Others: Portraits of Humanity from Around the World (formerly 6 Billion Others). It is worth pausing for a moment to consider this project. During a six-year period starting in 2003, 7 Billion Others compiled over 6,000 video testimonies from 84 countries, with participants answering 'universal' questions about fear, love, death and marriage. Featuring a boxy 


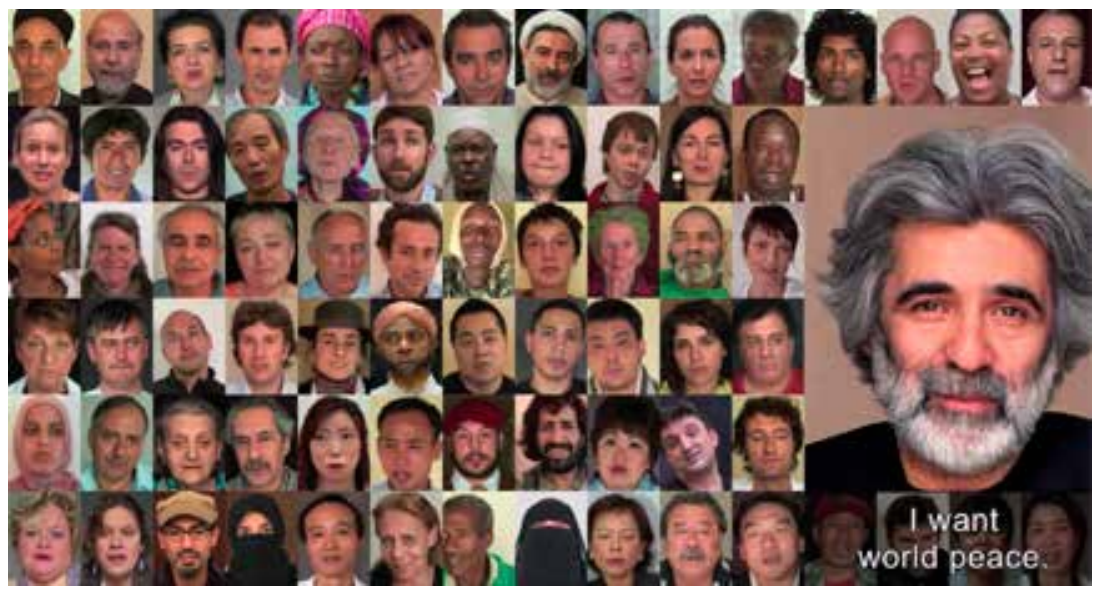

Figure 4.8 A multitude of faces in a mosaic video of 7 Billion Others. Courtesy of GoodPlanet Foundation.

aspect ratio that encloses the face and eliminates the background, the anonymised participants speak directly to the camera while subtitles on the side translate or transcribe their testimonies. By framing faces according to a predetermined and unchanging model, 7 Billion Others thus aims to render them equivalent and interchangeable. This is confirmed by the project's grid-like videos (figure 4.8), which combine a multitude of faces, mostly looking into the camera, while the face and voice of one participant is highlighted as he or she speaks.

As Druick notes, 'despite its reliance on the close-up, the ambitions of the 7 Billion Others project are, as its title suggests, encyclopaedic and totalizing', with its database aesthetics evoking 'computational schemes to document and manage large populations' ${ }^{94}$ Indeed, it would not be a stretch to deem 7 Billion Others the digital culmination of a project of population management that shares its genesis with that of anthropometric portraiture as a codifying and parametric mode of colonial knowledge. In this sense, the project's title, and the fact that it has changed so as to reflect an increase in the world's population, lays bare its concern with quantity and quantifiability. This is visually reiterated in the project's book version, the cover of which is made up of hundreds of tiny, barely legible facial portraits.

Previously relegated to the semiotic function of a type, head-on portraiture reappears here codified as a number, but one that still carries a sense of 
foreboding, now in relation to the ecological risks of population explosion. As Arthus-Bertrand explains: 'We're in the middle of destroying life on Earth. When I was born, we had a world population of 2 billion; now it's 7 billion [...] But there isn't enough for everyone. There isn't enough water, enough fish, enough wood'. ${ }^{55}$ When placed alongside other Arthus-Bertrand projects, all of which have the Anthropocene as their narrative and epistemological substratum, 7 Billion Others betrays in its title anxieties regarding unchecked population growth. ${ }^{6}$

Human rehashes the themes and features of 7 Billion Others, with interviews structured around similar questions and the focus largely on the human face. Whether we consider the many versions and products it has generated, or the profusion of human faces it parades, Human thrives on accumulation and multiplicity. Like 7 Billion Others, the film is quasianthropometric in its formal, compositional and structural rigour: against a black background, in frontal positions and looking into the camera, well-lit faces are positioned either on the left or right of the frame, with subtitles on the side transcribing their statements. But whereas the numerical drive of 7 Billion Others is spatialised across mosaic compositions, in Human it is durationally stretched. At several moments, while one subject speaks to the camera and his or her testimony remains audible, the visual track is intercut with shots of other faces silently facing the camera, often unblinkingly and/or in slow motion. Although there is no voiceover narration, the film is organised around clearly defined themes, including happiness, love, marriage, sexuality, war, sickness, death and life. In the film's feature-length versions, subjects remain anonymised, but an option to include captions indicating their name and geographical provenance is available on the web versions and YouTube clips.

Like Fricke, Arthus-Bertrand justifies his portraiture-inspired formal choices as a physiognomic belief that 'faces' and 'looks' provide a 'powerful way of reaching the depths of the human soul. Each encounter brings you a step closer. Each story is unique'. ${ }^{97}$ In this context, it is no accident that the film's second instalment includes an interview with Caleb, a US soldier who recounts his encounter with an Iraqi soldier thus:

95 Yann Arthus-Bertrand, in Rachel Segal Hamilton, 'Meet Filmmaker Yann Arthus-Bertrand Director of Woman' (n/d), https://www.canon.co.uk/pro/stories/woman-documentarydirector-yann-arthus-bertrand/\#: :text=\%22When $\% 201 \% 20 w a s \% 2 o b o r n \% 2 C \% 20 w e, \% 2 C \% 20$ enough\%2owood...\%22 (last accessed 25 August 2020).

96 See Druick, '“A Wide-Angle View of Fragile Earth”', 397-399.

97 Yann Arthus-Bertrand, 'Introduction', Human Press Kit (n/d), available at https://www. human-themovie.org (last accessed December 212016 ), 4. 
There is a moment - and the reason his face is always going to be with me - there is a moment when he looked at me. Our eyes met and at that moment, it was like everything else disappeared. It was just two people looking each other in the eyes. For a moment connecting like two human beings in an event that is beyond any of their control. At that moment, he wasn't a terrorist, he wasn't an insurgent, he wasn't an Iraqi. He was a scared man and he was asking me for help. From that moment on, the war changed for me. It became a little more scary and it became a little more [...] I started to question decisions a little more because of that event. It put a face.

Caleb's testimony brings to mind the philosophy of Emmanuel Levinas, for whom the intersubjective encounter establishes an ethical relationship whereby the face of the other, in its ungraspable strangeness, commands acts of responsibility as a gateway into what Levinas terms 'the absolutely other', that is to say, infinity itself. ${ }^{9}$ For Levinas, to look in the eyes of a face is to look at the face of all humans: the 'presence of the face, the infinity of the other, is a destituteness, a presence of the third party (that is, of the whole of humanity which looks at us), and a command that commands commanding'. ${ }^{99}$ Although Levinas is no doubt concerned with the actual, indeterminate face-to-face encounter (as in Caleb's case), his remarks shed some light on Human, which not only believes in the powers of the destitute face of the 'other' in its appeal to morality, but also in the power of cinema to act as a vehicle for a mediated encounter with multiplying faces that together morph into the face of humanity.

Whether or not the film is successful at the task it sets for itself will depend on how much one subscribes to a Levinasian ethics of 'otherness'. To the credit of Human's interviewers and editors, many of the stories told, in the manner they are told, are compelling: there is a sense these are genuine people telling their own stories with their faces, words and voices, an aspect even more pronounced in the longer individual videos available on the film's YouTube channel. On the other hand, if we are to side with Levinas's opponent Alain Badiou, as I do myself, Human is proof of the pernicious logic that supports an ethics of difference and 'its catechism of good will'. ${ }^{100}$ This is the case especially when we turn to its privileging of emotional

98 Emmanuel Levinas, Totality and Infinity: An Essay on Exteriority, trans. Alphonso Lingis (The Hague, Boston and London: Martinus Nijhoff Publishers, 1979), 195.

99 Ibid., 213.

100 Alain Badiou, Ethics: An Essay on the Understanding of Evil (London and New York: Verso, 2012), 20. 
testimonies and stories of suffering, which, to cite Badiou, reinforces a 'negative and victimary definition of man' to the detriment of a politics based on human affirmation, agency and action. ${ }^{101}$ As Badiou sees it, the current orthodoxy of the 'rights for difference', which has its philosophical origins in Levinas, is at best commonsensical, at worst reactionary: 'in truth a tourist's fascination for the diversity of morals, customs and beliefs [...] Yes, the essential "objective" basis of ethics rests on a vulgar sociology, directly inherited from the astonishment of the colonial encounter with savages'. ${ }^{102}$ Indeed, both Human and 7 Billion Others not merely show this to be the case so much as they reinforce this ethic's reliance on tropes of faciality as a colonial inheritance.

One could go so far as to say that 7 Billion Others and Human recall the 'systematic naming, categorization, and isolation of an otherness' of anthropometric photography as once defined by Allan Sekula. ${ }^{103}$ The stress here is on quantity, informed by a statistical belief in comparison and physiognomic frames of reference and visuality - a belief that the face itself, alone, isolated, archived and multiplied, can reveal both the commonalities and divergences across humankind. Incidentally, Sekula noted, this numerical impetus was a condemnable feature of Edward Steichen's supremely popular exhibition The Family of Man (1955), described by Carl Sandburg in its book version as a 'multiplication table of living breathing human faces'. ${ }^{104}$ For Sekula, The Family of Man was a site where 'arithmetic and humanism collide': 'The statistics that seek to legitimate the exhibition, to demonstrate its value, begins to carry a deeper sense: the truth being promoted here is one of enumeration'. ${ }^{105}$ More recently, Janine Marchessault has treated the exhibition as a more complex project and asked us to reconsider it in terms of a contradiction 'between Steichen's desire to foreground commonality in the face of possible nuclear warfare that would end human life on the planet and the US government's new ideological war'. ${ }^{106}$

101 Ibid., 16.

102 Ibid., 26.

103 Allan Sekula, 'The Traffic in Photographs' in Allan Sekula, Photography Against the Grain: Essays and Photo Works, 1973-1983 (Nova Scotia: The Press of the Nova Scotia, 1984), 77-101; 79. 104 Carl Sandburg, quoted in Sekula, 'The Traffic in Photographs', 9o, 93. The Family of Man comprised 503 photographs taken in 68 countries by 273 photographers, attracting 9 million people in 69 countries.

105 Ibid., 93.

106 Janine Marchessault, Ecstatic Worlds: Media, Utopia, Ecologies (Cambridge, MA, and London: MIT Press, 2017), 24. Crucial to Marchessault's argument is what she sees as The Family of Man's 


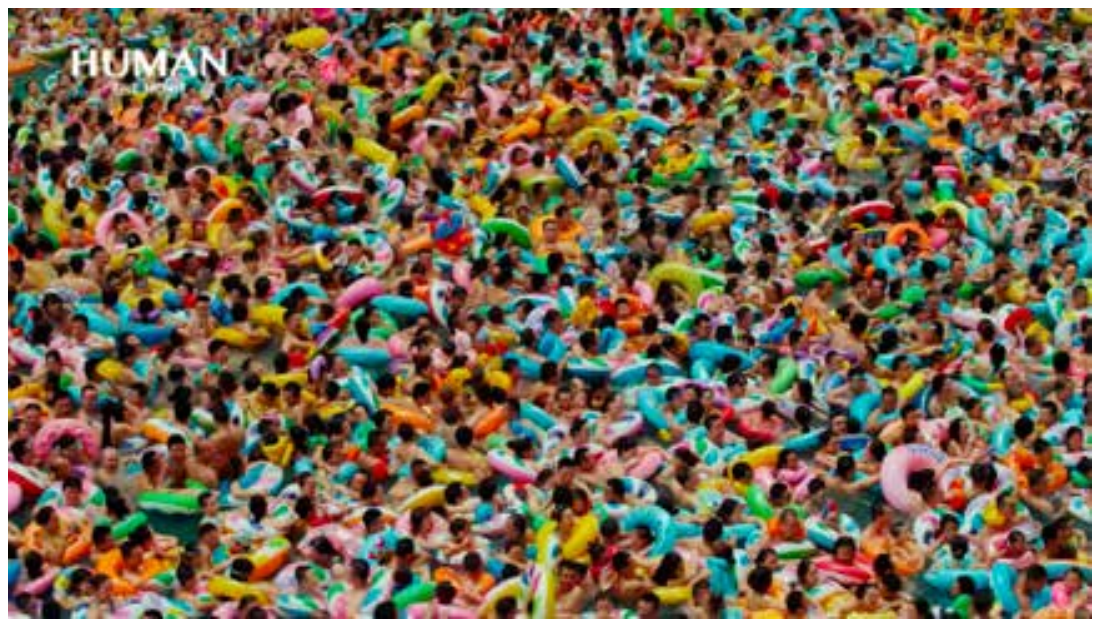

Figure 4.9 A sea of faces in Human (2015) makes visible anxieties over population explosion. Courtesy of GoodPlanet Foundation.

Human replicates both the arithmetic inflection of The Family of Man and its anxieties about the disappearance of the human race. Granted, the latter is not figured as a nuclear-induced threat, nor is the idea of a doomed human species explicitly thematised (as in Samsara). But it is an idea that lurks beneath the film, especially when we consider the inclusion of Arthus-Bertrand's trademark aerial shots of land devastation, endangered landscapes and heavy industry, all of which, in line with his other works, visualise a world running out of resources. More broadly, Human's anxieties about the end of humanity are, as in 7 Billion Others, visually formulated in relation to overpopulation. But whereas in that project population explosion is tamed via schematic grid-like visual models, in Human it is made visible in overcrowded shots where faces turn into tiny illegible dots as part of an undifferentiated mass. These include a wave pool in China (figure 4.9), a collective wedding in Japan, a football match in Hamburg and military parades in different countries - many of which are stylised and fetishised through slow motion and some of them recalling Samsara's aforementioned time-lapse aerial shot of Mecca.

In tune with attendant physiognomic beliefs and anthropological discourses, nineteenth-century galleries of a global humanity constituted a response to the multiplication of faces increasingly crowding cities and accordingly reproduced and multiplied via technological means. The threat

much-overlooked centerpiece, 'a six-by-eight-foot glowing backlit color Milar transparency of a thermonuclear explosion', 38 . 
here, to cite Doane again, was 'the specter of an illegible strangeness and otherness', one that was in part countered by the discourse of 'the face as a universal language' and in part by the systematic differentiation of humanity according to evolutionary parameters. ${ }^{107}$ These overcrowded shots in Human and Samsara demonstrate that such a treat has not so much gone away as it has been exacerbated in our time in the face of population explosion and ensuing catastrophic prospects. In this context, the ubiquity of the face evident in Facebook, the selfie and facial recognition technologies designed with the very aim of recognising the face in the crowd, all speak to this threat of illegibility and attempt, in different ways and with different socio-political and socio-cultural consequences, to reassert the face as a recognisable unit, whether as a mode of self-presentation or as a means of surveillance and control. Human and Samsara are part and parcel of this phenomenon. ${ }^{108}$ Yet in light of their decidedly elegiac mode and their programmatic adherence to colonial modes of portraiture, their stilling and enclosure of the face is particularly striking. For it shows that whereas extinction discourse may have evolved in its causes and consequences, its face has remained remarkably intact. 
